\title{
Oleanane and Stigmasterol-Type Triterpenoid Derivatives from the Stem Bark of Albizia gummifera and Their Antibacterial Activities
}

\author{
Tamrat Tesfaye Ayele, ${ }^{1,2}$ Getahun Tadesse Gurmessa, ${ }^{1}$ Zelalam Abdissa, ${ }^{1}$ Girmaye Kenasa, ${ }^{3}$ \\ and Negera Abdissa $\mathbb{(}^{2}$ \\ ${ }^{1}$ Department of Chemistry, College of Natural and Computational Sciences, Nekemte, Wollega University, Ethiopia \\ ${ }^{2}$ Department of Chemistry, College of Natural Sciences, Jimma University, Jimma, Ethiopia \\ ${ }^{3}$ Department of Biology, College of Natural and Computational Sciences, Wollega University, Nekemte, Ethiopia
}

Correspondence should be addressed to Negera Abdissa; negeraabdisa@gmail.com

Received 26 October 2021; Revised 13 January 2022; Accepted 29 January 2022; Published 18 February 2022

Academic Editor: Liviu Mitu

Copyright (C) 2022 Tamrat Tesfaye Ayele et al. This is an open access article distributed under the Creative Commons Attribution License, which permits unrestricted use, distribution, and reproduction in any medium, provided the original work is properly cited.

\begin{abstract}
Chromatographic separation of methanol extract of stem bark of Albizia gummifera led to the isolation of two oleanane-type triterpenoids (1 and 2), a stigmasterol derivative (3), and stigmasterol (4). The structures of the compounds were elucidated based on 1D and 2D NMR spectroscopic data and comparing with reported literature values. The crude extract and the isolated compounds were evaluated for their antibacterial activities against five bacterial strains. Compounds 1, 2, and $\mathbf{4}$ showed marginal antibacterial activity with the growth inhibition zone ranging from 6.8 to $13.2 \mathrm{~mm}$ against the tested bacterial strains, with compounds 2 and $\mathbf{4}$ showing significant inhibition (13.0 and $13.2 \mathrm{~mm}$ ) against $S$. flexneri and S. typhimurium, respectively. While, the standard drug, gentamycin showed inhibition zone 20.0 and $24.0 \mathrm{~mm}$ against S. flexneri and S. typhimurium, respectively.
\end{abstract}

\section{Introduction}

The genus Albizia (family, Fabaceae) comprising of more than 160 species is widely distributed in subtropical and tropical regions with the major diversity in Africa and South America $[1,2]$. Albizia gummifera C.A. Smith is a species of native to sub-Saharan Africa and Madagascar [3] and commonly known in the indigenous medical system to treat various human ailments $[1,4,5]$. The extracts of different solvents have reported to possess antimicrobial [6], antigonorrheal [7], antiplasmodial, and antileishmanial [8] activities. The plant elaborates triterpenoids $[5,9]$ as a common metabolite with proapoptotic and antiplasmodial activities. The stem bark of A. gummifera has been commonly visited by traditional healers for the treatment of bacterial infection in the eastern part of Ethiopia. However, the phytochemical and biological profile of this plant is not exhaustively studied.
Thus, hereby, we report the isolation of four compounds (1-4) (Figure 1) from the stem bark of A. gummifera along with their antibacterial activities.

\section{Materials and Methods}

2.1. General Experimental Procedures. Solvents and reagents used for extraction and purification of the compounds were of analytical and HPLC grade. Analytical TLC precoated sheets ALUGRAM ${ }^{\circledR}$ Xtra SIL G/UV ${ }_{254}$ (layer: $0.20 \mathrm{~mm}$ silica gel 60 with the fluorescent indicator $U_{\mathrm{F} 254 / 365}$ ) were used for purity analysis. Silica gel 100-200 mesh was used for column chromatography. Visualization was made on TLC by spraying with $10 \% \mathrm{H}_{2} \mathrm{SO}_{4}$ acid solution and heating on a hot plate. NMR spectra were recorded on an Av600 MHz spectrometer (Bruker, Billerica, MA, USA). Chemical shifts were expressed in parts per million (ppm) downfield of trimethylsilane (TMS) as an internal 


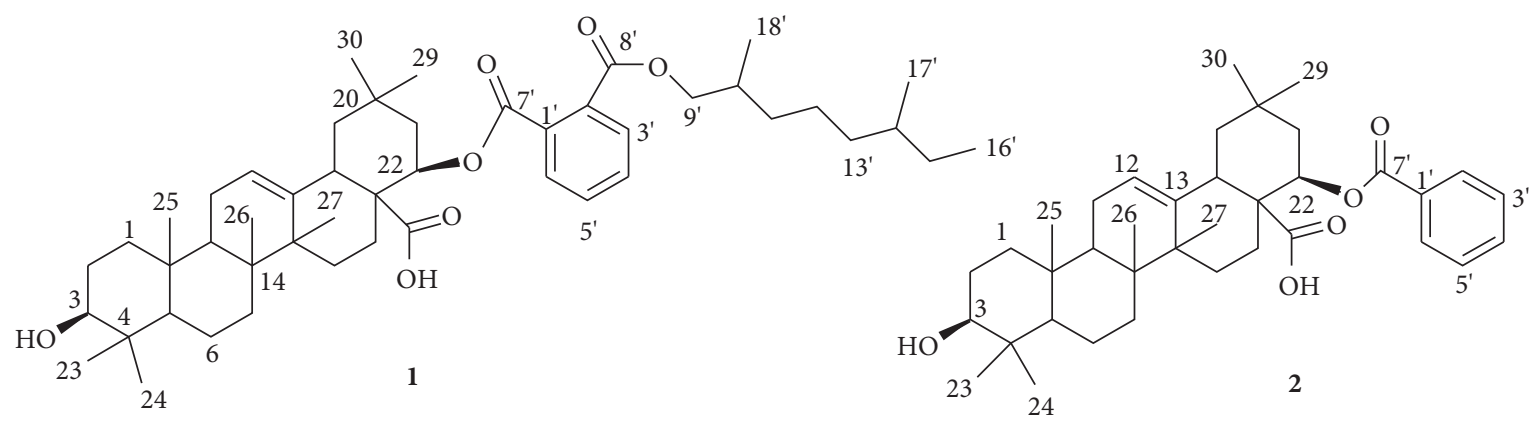

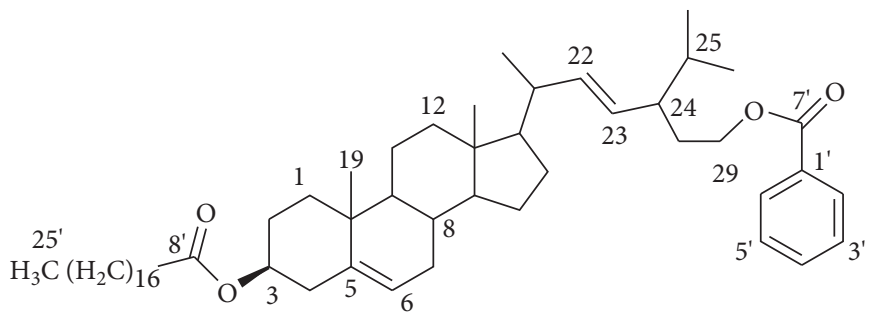

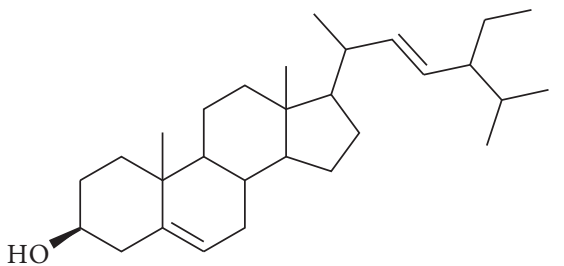

4

Figure 1: Structures of the isolated compounds from stem bark of A. gummifera.

reference. Whatman filter paper No. 3, 1\% dimethylsulfoxide (DMSO), Petri dishes, and gentamycin were used for antibacterial analysis.

2.2. Plant Materials. The stem bark of A. gummifera was collected from Wollega University, Nekemte campus, in September 2019. The plant was authenticated by botanist, Dr. Fikadu Gurmessa, and a voucher specimen (TTA004Ag) has been deposited in Wollega University Herbarium.

\subsection{Extraction and Isolation. The maceration extraction} was employed [10] in this experiment to extract secondary metabolites from the stem bark of A. gummifera. About $940 \mathrm{~g}$ of sample was extracted with methanol (2 L) three times each. The filtrate was evaporated using a rotary evaporator to yield $10 \mathrm{~g}$ of semisolid extract. The crude extract $(9 \mathrm{~g})$ was suspended in water and extracted with petroleum ether and chloroform to yield $3 \mathrm{~g}$ (yellow semisolid) and $4 \mathrm{~g}$ (brown semisolid), respectively. Then, $2.50 \mathrm{~g}$ of crude extract of petroleum ether was adsorbed on $3 \mathrm{~g}$ of silica gel and subjected to column chromatography. The column was eluted with $n$-hexane $(100 \%)$ and continued with $n$-hexane/ethyl acetate $(95 / 5,90 / 10,85 / 15,80 /$ $20, \ldots, 25 / 75, v / v)$ to obtain 77 fractions, each $200 \mathrm{~mL}$. The fractions were grouped into six subfractions (1-6) based on their TLC profile. Subfraction 2 showed a precipitate and washed repeatedly with petroleum ether to obtain a white powder compound (4) (20 mg). Subfraction 4 was subjected to small column chromatography over silica gel and eluted with $n$-hexane in increasing gradient of ethyl acetate to afford a light yellow powder compound (1) $(20 \mathrm{mg})$.

The chloroform crude $(3.50 \mathrm{~g})$ was also subjected to column chromatography over silica gel and eluted with dichloromethane/ethyl acetate $(80 / 20,70 / 30,60 / 40$, and
50/50), each $200 \mathrm{~mL}$. Sixty-four fractions were collected and combined into five (1-5) subfractions. Subfraction 5 was again subjected to small column chromatography over silica gel and eluted with $n$-hexane/ethyl acetate $(80 / 20,70 / 30$, and $60 / 40)$ to afford a white powder compound (3) $(21 \mathrm{mg})$ and light yellow compound (2) (13 mg).

2.4. Pathogenic Bacterial Strains. Five pathogenic bacterial strains, one Gram-positive (Staphylococcus aureus (ATCC25923)) and four Gram-negative (Escherichia coli (ATCC25922), Pseudomonas aeruginosa (ATCC27853), Salmonella typhimurium (ATCC13311), and Shigella flexneri (ATCC29903)) were obtained from the Department of Biology, Wollega University, and used for evaluation of antibacterial activities.

2.5. Antibacterial Assay of the Isolated Compounds. The paper disc diffusion method was employed to determine the antibacterial activities of the isolated compounds as described by Kumara et al. [11] with slight modification. The pathogens were seeded on Muller-Hinton agar media (model), and simultaneously, sterile circular discs of $6 \mathrm{~mm}$ in diameter were prepared from Whatman filter paper No. 3. The solutions of crude extract $20 \mu \mathrm{g} / \mathrm{mL}$, each and compounds (1, 2 and 4$)(10 \mu \mathrm{g} / \mathrm{mL}$, each), were prepared in $1 \%$ dimethylsulfoxide (DMSO). The discs were impregnated with these solutions and applied aseptically to the Petri dishes of microbial culture [12]. The applied substances let to diffuse to the agar for half an hour and then incubated at $35^{\circ} \mathrm{C}$ for $24 \mathrm{~h}$. Both DMSO (1\%) and gentamycin (impregnated disc, $10 \mu \mathrm{g} / \mathrm{mL}$ ) were used as negative and positive controls, respectively. All tests were performed in triplicate, and zone of inhibition was measured from the edge of each disc with a ruler. 
2.6. Statistical Analysis. Data were measured as mean \pm SD. Statistical analysis was performed using SPSS version 20 Software. The global comparison was done using two-way ANOVA followed by the least significant difference (LSD) multiple comparison test. Pairwise testing was done with the help of the unpaired post hoc test. $P<0.05$ implies that it is statistically significant.

\section{Results and Discussion}

Compound 1 was obtained as a light yellow solid. The ${ }^{1} \mathrm{H}$ NMR spectrum (Table 1) displayed seven singlets at $\delta_{\mathrm{H}} 0.99$ (3H, s, H-23), 0.78 (3H, s, H-24), 0.93 (3H, s, H-25), 0.77 (3H, s, H-26), 1.13 (3H, s, H-27), 0.92 (3H, s, H-29), and 1.43 $(3 \mathrm{H}, \mathrm{s}, \mathrm{H}-30)$, integrated for three protons each for seven methyl groups; a triplet olefinic protons resonating at $\delta_{\mathrm{H}}$ $5.27(1 \mathrm{H}, \mathrm{t}, J=3.7 \mathrm{~Hz}, \mathrm{H}-12)$, a doublet of doublets methine proton at $\delta_{\mathrm{H}} 3.21(1 \mathrm{H}, \mathrm{dd}, J=11.3,4.3 \mathrm{~Hz}, \mathrm{H}-3)$, and two methine protons signals at $\delta_{\mathrm{H}} 1.56(1 \mathrm{H}, \mathrm{m}, \mathrm{H}-9)$ and 2.82 $(1 \mathrm{H}, \mathrm{dd}, J=13.8,4.7 \mathrm{~Hz}, \mathrm{H}-18)$, which are the typical characteristics of an oleanane-type of triterpene [13-15]. Furthermore, di-ortho/meta coupling protons at $\delta_{\mathrm{H}} 7.53$ $\left(2 \mathrm{H}, \mathrm{td}, J=5.8,3.5 \mathrm{~Hz}, \mathrm{H}-4^{\prime}\right.$ and $\left.\mathrm{H}-5^{\prime}\right)$ and the deshielded proton signals at $\delta_{\mathrm{H}} 7.71\left(2 \mathrm{H}, \mathrm{dd}, J=12.5,5.7,3.3 \mathrm{H} \mathrm{z}, \mathrm{H}-3^{\prime}\right.$ and $\left.\mathrm{H}-6^{\prime}\right)$ are a characteristic of ortho-disubstituted benzene moiety [15]. The oxygenated methylene protons at $\delta_{\mathrm{H}} 4.08$ $\left(2 \mathrm{H}, \mathrm{d}, J=6.7 \mathrm{~Hz}, \mathrm{H}-1^{\prime \prime}\right)$, multiple proton signals for methine protons at $\delta_{\mathrm{H}} 2.04\left(1 \mathrm{H}, \mathrm{m}, \mathrm{H}-2^{\prime \prime}\right), 1.32\left(1 \mathrm{H}, \mathrm{m}, \mathrm{H}-6^{\prime \prime}\right)$, two doublet for methyl protons at $\delta_{\mathrm{H}} 0.99(3 \mathrm{H}, \mathrm{d}, J=6.4 \mathrm{~Hz}$, $\left.\mathrm{H}-9^{\prime \prime}\right), 0.90\left(3 \mathrm{H}, \mathrm{d}, J=6.0 \mathrm{~Hz}, \mathrm{H}-10^{\prime \prime}\right)$, and one triplet for methyl protons at $\delta_{\mathrm{H}} 0.92\left(3 \mathrm{H}, \mathrm{t}, J=3.7 \mathrm{~Hz}, \mathrm{H}-8^{\prime \prime}\right)$ indicate the presence of geranyl unit (monoterpene) linked through an ester bond.

The ${ }^{13} \mathrm{C}$ NMR spectrum (Table 1 ) showed carbon signals for 48 carbon atoms, of which 30 carbon atoms are for aglycone core, 8 carbon atoms for phthalate moiety, and 10 carbon atoms for the two isoprene chains. The downfield shifted carbon signals at $\delta_{\mathrm{C}} 167.8\left(\mathrm{C}-7^{\prime}\right), 167.7\left(\mathrm{C}-8^{\prime}\right), 132.5$ $\left(\mathrm{C}-2^{\prime}\right), 132.4\left(\mathrm{C}-1^{\prime}\right), 130.9\left(\mathrm{C}-4^{\prime}\right.$ and $\left.\mathrm{C}-5^{\prime}\right)$, and $128.9\left(\mathrm{C}-3^{\prime}\right.$ and $\left.\mathrm{C}-6^{\prime}\right)$ are carbons for phthalate moiety, while the signals resonate at $\delta_{\mathrm{C}} 71.8\left(\mathrm{C}-1^{\prime \prime}\right)$ and $27.7\left(\mathrm{C}-2^{\prime \prime}\right.$ and $\left.\mathrm{C}-3^{\prime \prime}\right)$, three methyl carbons resonate at $11.0\left(\mathrm{C}-8^{\prime \prime}\right), 19.2\left(\mathrm{C}-9^{\prime \prime}\right)$, and 14.1 $\left(\mathrm{C}-10^{\prime \prime}\right)$ for the geranyl unit (monoterpene), whereas the signals of seven methyls of aglycone core (C-23, C-24, C-25, C-26, C-27, C-29, and C-30) are resonated at $\delta_{\mathrm{C}} 28.1,15.5$, $15.3,17.1,25.9,33.1$, and 23.7, respectively. The signals resonating at $\delta_{\mathrm{C}} 38.4(\mathrm{C}-1), 79.0(\mathrm{C}-3), 122.6(\mathrm{C}-12), 143.6$ (C-13), 40.9 (C-18), and 183.7 (C-28) are in accordance with the reported literature data for oleanoloate [13-16] except signal at $\delta_{\mathrm{C}} 68.2(\mathrm{C}-22)$ which could be due to the oxygen attachment with the phthalate moiety. The gross structure of the aglycone and position of the substituent was determined by analysis of ${ }^{1} \mathrm{H}^{-}{ }^{1} \mathrm{H}$ COSY and $\mathrm{HMBC}$ experiments (Figure 2). The ${ }^{1} \mathrm{H}-{ }^{1} \mathrm{H}$ COSY cross-peaks showed the coupling of hydroxymethine proton $\mathrm{H}-3\left(\delta_{\mathrm{H}} 3.21\right)$ with $\mathrm{H}-2\left(\delta_{\mathrm{H}} 1.64\right)$, H-12 $\left(\delta_{\mathrm{H}} 5.27\right)$ with H-11 $\left(\delta_{\mathrm{H}} 1.90\right), \mathrm{H}-15\left(\delta_{\mathrm{H}} 1.32\right)$ with H-16 $\left(\delta_{\mathrm{H}} 0.94\right), \mathrm{H}-18\left(\delta_{\mathrm{H}} 2.82\right)$ with H-19 $\left(\delta_{\mathrm{H}} 1.61\right)$, and $\mathrm{H}-21\left(\delta_{\mathrm{H}} 1.71\right)$ with $\mathrm{H}-22\left(\delta_{\mathrm{H}} 4.22\right)$ enabled to construct the structure of aglycone. The correlation of proton $\mathrm{H}-3^{\prime}\left(\delta_{\mathrm{H}}\right.$
7.71) with $\mathrm{H}-4^{\prime}$ and $\mathrm{H}-5^{\prime}\left(\delta_{\mathrm{H}} 7.53\right)$ through ortho/meta coupling further confirm the phthalate moiety. Similarly, the cross-peaks from oxymethylene proton $\mathrm{H}-1^{\prime \prime}\left(\delta_{\mathrm{H}} 4.08\right)$ with $\mathrm{H}-2^{\prime \prime}\left(\delta_{\mathrm{H}} 2.04\right)$ and $\mathrm{H}-5^{\prime \prime}\left(\delta_{\mathrm{H}} 1.78\right)$ with $\mathrm{H}-6^{\prime \prime}\left(\delta_{\mathrm{H}} 1.32\right)$ also revealed the geranyl unit (monoterpene).

The long-range HMBC coupling (Figure 2) from oxymethine proton at $\delta_{\mathrm{H}} 4.22(\mathrm{H}-22)$ to carbon signal at $\delta_{\mathrm{C}} 23.6$ $(\mathrm{C}-16), \delta_{\mathrm{C}} 38.7(\mathrm{C}-21), \delta_{\mathrm{C}} 30.7(\mathrm{C}-20)$, and $\delta_{\mathrm{C}} 167.8\left(\mathrm{C}-7^{\prime}\right)$ enabled to establish the phthalate moiety at C-22 through an ester bond. The oxymethylene protons peaks at $\delta_{\mathrm{H}} 4.08(\mathrm{H}-$ $1^{\prime \prime}$ showed an $\mathrm{HMBC}$ correlation to carbon signals at $\delta_{\mathrm{C}}$ $167.7\left(\mathrm{C}-8^{\prime}\right)$ and $\left.\delta_{\mathrm{C}} 27.7\left(\mathrm{C}-2^{\prime \prime}\right)\right)$ confirmed the attachment of geranyl unit at $\mathrm{C}-8^{\prime}$ of phthalate. Thus, based on the above spectroscopic analysis, the structure of compound $\mathbf{1}$ was deduced to be a 3-hydroxy-22-(2-((2, 6-dimethyloctyloxy) carbonyl) benzoyloxy)olean-12-en-28-oic acid.

Compound 2 was obtained as a yellow powder. The NMR spectral data showed similar spectral feature with compound 1 except for some substituted positions. The ${ }^{1} \mathrm{H}$ NMR spectrum (Table 1) displayed five aromatic protons at $\delta_{\mathrm{H}} 7.70\left(1 \mathrm{H}, \mathrm{dd}, J=5.7,3.3 \mathrm{~Hz}, \mathrm{H}-2^{\prime}\right.$ and $\left.\mathrm{H}-6^{\prime}\right)$ and $\delta_{\mathrm{H}} 7.53$ $\left(1 \mathrm{H}, \mathrm{dd}, J=5.7,3.3 \mathrm{~Hz}, \mathrm{H}-3^{\prime}, \mathrm{H}-4^{\prime}\right.$, and $\left.\mathrm{H}-5^{\prime}\right)$, containing HSQC correlations with carbons at $\delta_{\mathrm{C}} 128.8\left(\mathrm{C}-2^{\prime}\right.$ and C- $\left.6^{\prime}\right)$ and $130.9\left(\mathrm{C}-3^{\prime}, \mathrm{C}-4^{\prime}\right.$, and $\left.\mathrm{C}-5^{\prime}\right)$, respectively. However, the ${ }^{13} \mathrm{C}$ NMR spectrum (Table 1 ) showed an esteric carbonyl carbon at $\delta_{\mathrm{C}} 167.8\left(\mathrm{C}-7^{\prime}\right)$ and one quaternary carbon at $\delta_{\mathrm{C}}$ $132.5\left(\mathrm{C}-1^{\prime}\right)$, indicating the benzoate linked to oleanolic moiety. The long-range HMBC correlations (Figure 2) between oxymethine protons at $\delta_{\mathrm{H}} 4.22(\mathrm{H}-22)$ and carbon signals at $\delta_{\mathrm{C}} 38.7(\mathrm{C}-21), \delta_{\mathrm{C}} 30.7(\mathrm{C}-20)$, and $\delta_{\mathrm{C}} 23.6(\mathrm{C}-16)$ and carbonyl carbon at $\delta_{\mathrm{C}} 167.8\left(\mathrm{C}-7^{\prime}\right)$ established the linkage of benzoate at C-22. Therefore, based on the above findings, the structure of compound 2 was defined to be 22(benzoyloxy)-3-hydroxyolean-12-en-28-oic acid.

Compound 3 was obtained as a white solid. The ${ }^{1} \mathrm{H}$ and ${ }^{13} \mathrm{C}$ NMR spectra data are similar to that of stigmasterol (4) (coisolated from the same fraction) except for some signals for C-28, C-29, and C-3 of the stigmasterol (could be due to the substitution effect). The ${ }^{1} \mathrm{H}$ NMR spectrum displayed doublet of doublets oxymethylene protons at $\delta_{\mathrm{H}} 4.22(2 \mathrm{H}$, $\mathrm{dd}, J=11.4,5.9 \mathrm{~Hz}, \mathrm{H}-29)$. These protons showed a longrange $\mathrm{HMBC}$ cross-coupling (Figure 3 ) with carbonyl easter of benzoate moiety, whose presence is evidenced from strongly deshielded doublet of doublets at $\delta_{\mathrm{H}} 7.70(2 \mathrm{H}, \mathrm{dd}$, $J=5.7,3.3 \mathrm{~Hz}$ ) for $\mathrm{H}-2^{\prime \prime}$ and $\mathrm{H}-6^{\prime \prime}$ and multiplet at $\delta_{\mathrm{H}} 7.53$ ( $3 \mathrm{H}$, for $\mathrm{H}-3^{\prime \prime}, \mathrm{H}-4^{\prime \prime}$, and $\left.\mathrm{H}-5^{\prime \prime}\right)$, indicating that the position of the benzoate substituent at C-29.

The ${ }^{1} \mathrm{H}$ NMR spectrum also showed signals for aliphatic carboxylate (Table 1 ). In this regard, ${ }^{13} \mathrm{C}$ NMR spectrum showed that a downfield shifted carbon signal at $\delta_{\mathrm{C}} 178.5$ is assignable to carbonyl carbon $\left(\mathrm{C}-1^{\prime}\right)$ and the signal at $\delta_{\mathrm{C}} 33.8$ for C-2'. The HSQC spectrum confirmed the connectivity between protons at $\delta_{\mathrm{H}} 2.35(2 \mathrm{H}, \mathrm{t}, J=7.5 \mathrm{~Hz}), 1.65(2 \mathrm{H}, \mathrm{dt}$, $J=34.2,7.1 \mathrm{~Hz}), 1.33(2 \mathrm{H}, \mathrm{m})$, and $0.91(3 \mathrm{H}, \mathrm{t}, J=6.8 \mathrm{~Hz})$ with carbon atoms at $\delta_{\mathrm{C}} 33.8\left(\mathrm{C}-2^{\prime}\right), 24.7\left(\mathrm{C}-3^{\prime}\right), 23.0(\mathrm{C}-$ $\left.17^{\prime}\right)$, and $14.1\left(\mathrm{C}-18^{\prime}\right)$, respectively.

The triplet methylene protons at $\delta_{\mathrm{H}} 2.35(2 \mathrm{H}, \mathrm{t}$, $J=7.6 \mathrm{~Hz}$ ) showed strong HMBC correlations with carbon at $\delta_{\mathrm{C}} 178.5$ (carbonyl carbon, C-1') and $\delta_{\mathrm{C}} 24.7\left(\mathrm{C}-3^{\prime}\right)$, 
TABle 1: ${ }^{1} \mathrm{H}$ NMR and ${ }^{13} \mathrm{C}$ NMR (600 MHz) spectroscopic data for compounds 1-4 in $\mathrm{CDCl}_{3}$.

\begin{tabular}{|c|c|c|c|c|c|c|c|c|}
\hline \multirow{2}{*}{$\mathrm{C} / \mathrm{H}$} & \multicolumn{2}{|l|}{1} & \multicolumn{2}{|l|}{2} & \multicolumn{2}{|l|}{3} & \multicolumn{2}{|l|}{4} \\
\hline & $\delta_{\mathrm{H}}(\mathrm{m}, J$ in $\mathrm{Hz})$ & $\delta_{\mathrm{C}}(\mathrm{ppm})$ & $\delta_{\mathrm{H}}(\mathrm{m}, J$ in $\mathrm{Hz})$ & $\delta_{\mathrm{C}}(\mathrm{ppm})$ & $\delta_{\mathrm{H}}(\mathrm{m}, J$ in $\mathrm{Hz})$ & $\delta_{\mathrm{C}}(\mathrm{ppm})$ & $\delta_{\mathrm{H}}(\mathrm{m}, J$ in $\mathrm{Hz})$ & $\delta_{\mathrm{C}}(\mathrm{ppm})$ \\
\hline 1 & $1.62(\mathrm{~m})$ & 38.4 & $1.62(\mathrm{~m})$ & 38.4 & $1.14(\mathrm{~m})$ & 37.3 & $1.14(\mathrm{~m})$ & 37.3 \\
\hline 2 & $1.64(\mathrm{~m})$ & 27.2 & $1.64(\mathrm{~m})$ & 27.2 & $1.55(\mathrm{~m})$ & 31.6 & $1.55(\mathrm{~m})$ & 31.7 \\
\hline 3 & $3.21(\mathrm{dd}, 11.3,4.3)$ & 79.0 & $3.22(\mathrm{dd}, 11.3,4.3)$ & 79.0 & $3.52(\mathrm{td}, 11.2,5.7)$ & 71.8 & $3.52(\mathrm{td}, 11.2,5.7)$ & 71.8 \\
\hline 4 & - & 38.8 & - & 39.3 & $2.30(\mathrm{~d}, 5.0)$ & 42.2 & $2.30(\mathrm{~d}, 5.0)$ & 42.2 \\
\hline 5 & $0.74(\mathrm{~m})$ & 55.2 & $0.75(\mathrm{~m})$ & 55.2 & - & 140.7 & - & 140.8 \\
\hline 6 & $1.57(\mathrm{~m})$ & 18.3 & $1.56(\mathrm{~m})$ & 18.3 & $5.35(\mathrm{dd}, 5.4,1.9)$ & 121.7 & $5.35(\mathrm{dd}, 5.4,1.9)$ & 121.7 \\
\hline 7 & $1.45(\mathrm{~m})$ & 32.6 & $1.36(\mathrm{~m})$ & 32.6 & $1.83(\mathrm{~m})$ & 31.9 & $1.83(\mathrm{~m})$ & 31.9 \\
\hline 8 & - & 39.3 & - & 37.1 & $1.45(\mathrm{~m})$ & 31.9 & $1.45(\mathrm{~m})$ & 31.9 \\
\hline 9 & $1.56(\mathrm{~m})$ & 47.6 & $1.56(\mathrm{~m})$ & 47.6 & $0.93(\mathrm{~m})$ & 50.2 & $0.93(\mathrm{~m})$ & 50.2 \\
\hline 10 & - & 37.1 & - & 38.8 & - & 36.5 & - & 36.5 \\
\hline 11 & $1.90(\mathrm{~m})$ & 23.4 & $1.90(\mathrm{~m})$ & 23.4 & $1.30(\mathrm{~m})$ & 22.7 & $1.30(\mathrm{~m})$ & 21.1 \\
\hline 12 & $5.27(\mathrm{t}, 3.7)$ & 122.6 & $5.28(\mathrm{t}, 3.7)$ & 122.6 & $1.83(\mathrm{~m})$ & 39.7 & $1.83(\mathrm{~m})$ & 39.7 \\
\hline 13 & - & 143.6 & - & 143.6 & - & 42.3 & - & 42.3 \\
\hline 14 & - & 41.6 & - & 41.6 & $1.00(\mathrm{~m})$ & 56.9 & $1.00(\mathrm{~m})$ & 56.9 \\
\hline 15 & $1.32(\mathrm{~m})$ & 28.9 & $1.08(\mathrm{~m})$ & 27.7 & $1.55(\mathrm{~m})$ & 24.4 & $1.55(\mathrm{~m})$ & 24.4 \\
\hline 16 & $0.94(\mathrm{~m})$ & 23.6 & $1.42(\mathrm{~m})$ & 23.6 & $1.33(\mathrm{~m})$ & 28.9 & $1.33(\mathrm{~m})$ & 28.9 \\
\hline 17 & - & 46.5 & - & 46.5 & $1.15(\mathrm{~m})$ & 56.0 & $1.15(\mathrm{~m})$ & 56.0 \\
\hline 18 & $2.82(\mathrm{dd}, 13.8,4.7)$ & 40.9 & $2.82(\mathrm{dd}, 13.8,4.7)$ & 41.0 & $0.68(\mathrm{~s})$ & 12.1 & $0.68(\mathrm{~s})$ & 12.0 \\
\hline 19 & $1.62(\mathrm{~m})$ & 45.9 & $1.15 ; 1.64(\mathrm{~m})$ & 45.9 & $1.03(\mathrm{~s})$ & 19.8 & $1.03(\mathrm{~s})$ & 19.8 \\
\hline 20 & - & 30.7 & - & 30.7 & $2.04(\mathrm{~m})$ & 40.5 & $2.04(\mathrm{~m})$ & 40.5 \\
\hline 21 & $1.70(\mathrm{~m})$ & 38.7 & $1.70(\mathrm{~m})$ & 38.7 & $1.04(\mathrm{~m})$ & 21.1 & $1.04(\mathrm{~m})$ & 21.2 \\
\hline 22 & $4.22(\mathrm{dd}, 11.5,5.9)$ & 68.2 & $4.22(\mathrm{dd}, 11.4,5.9)$ & 68.2 & $5.15(\mathrm{~m})$ & 138.3 & $5.15(\mathrm{~m})$ & 138.3 \\
\hline 23 & $0.99(\mathrm{~s})$ & 28.1 & $1.00(\mathrm{~s})$ & 28.1 & $5.03(\mathrm{dd}, 15.1,8.8)$ & 129.3 & $5.03(\mathrm{dd}, 15.1,8.8)$ & 129.3 \\
\hline 24 & $0.78(\mathrm{~s})$ & 15.5 & $0.76(\mathrm{~s})$ & 15.5 & $1.55(\mathrm{~m})$ & 51.3 & $1.55(\mathrm{~m})$ & 51.2 \\
\hline 25 & $0.93(\mathrm{~s})$ & 15.3 & $0.93(\mathrm{~s})$ & 15,3 & $1.45(\mathrm{~m})$ & 31.9 & & 45.8 \\
\hline 26 & 0.77 (s) & 17.1 & $0.75(\mathrm{~s})$ & 17.1 & $0.94(\mathrm{~m})$ & 11.0 & $0.82(\mathrm{~d}, 6.6)$ & 21.1 \\
\hline 27 & $1.13(\mathrm{~s})$ & 25.9 & $1.16(\mathrm{~s})$ & 25.9 & $1.42(\mathrm{~m})$ & 23.7 & $0.80(\mathrm{~d}, 6.6)$ & 19.0 \\
\hline 28 & - & 183.7 & - & 183.5 & $1.70(\mathrm{~m})$ & 38.7 & $0.71(\mathrm{~s})$ & 25.4 \\
\hline 29 & $0.92(\mathrm{~s})$ & 33.1 & $0.94(\mathrm{~s})$ & 33.1 & $4.22(\mathrm{dd}, 11.4,5.9)$ & 68.2 & $1.03(\mathrm{~s})$ & 12.3 \\
\hline 30 & $1.43(\mathrm{~s})$ & 23.7 & $1.43(\mathrm{~s})$ & 23.8 & - & - & & \\
\hline $1^{\prime}$ & - & 132.4 & - & 132.5 & - & 132.5 & & \\
\hline $2^{\prime}$ & - & 132.5 & $7.70(\mathrm{dd}, 5.7,3.3)$ & 128.8 & $7.70(\mathrm{dd}, 5.7,3.3)$ & 128.8 & & \\
\hline $3^{\prime}$ & $7.71(\mathrm{dd}, 12.5,5.7,3.3)$ & 128.8 & $7.53(\mathrm{dd}, 5.7,3.3)$ & 130.9 & $7.53(\mathrm{dd}, 5.7,3.3)$ & 130.9 & & \\
\hline $4^{\prime}$ & $7.53(\mathrm{dt}, 5.8,3.5)$ & 130.9 & $7.53(\mathrm{dd}, 5.7,3.3)$ & 130.9 & $7.53(\mathrm{dd}, 5.7,3.3)$ & 130.9 & & \\
\hline $5^{\prime}$ & $7.53(\mathrm{dt}, 5.8,3.5)$ & 130.9 & $7.53(\mathrm{dd}, 5.7,3.3)$ & 130.9 & $7.53(\mathrm{dd}, 5.7,3.3)$ & 130.9 & & \\
\hline $6^{\prime}$ & $7.71(\mathrm{dd}, 12.5,5.7,3.3)$ & 128.9 & $7.70(\mathrm{dd}, 5.7,3.3)$ & 128.8 & $7.70(\mathrm{dd}, 5.7,3.3)$ & 128.8 & & \\
\hline $7^{\prime}$ & - & 167.8 & - & 167.8 & - & 167.8 & & \\
\hline $8^{\prime}$ & - & 167.7 & & & - & 178.5 & & \\
\hline $9^{\prime}$ & $4.08(\mathrm{~d}, 6.7)$ & 71.8 & & & $2.35(t, 7.5)$ & 33.8 & & \\
\hline $10^{\prime}$ & $2.04(\mathrm{~m})$ & 27.7 & & & $1.65(\mathrm{dt}, 34.2,7.1)$ & 24.7 & & \\
\hline $11^{\prime}$ & $1.01(\mathrm{~m})$ & 27.7 & & & $1.86(\mathrm{~m})$ & 31.9 & & \\
\hline $12^{\prime}$ & $1.62(\mathrm{~m})$ & 22.9 & & & $1.55(\mathrm{~m})$ & 31.9 & & \\
\hline $13^{\prime}$ & $1.78(\mathrm{~m})$ & 32.4 & & & $1.30-1.45(\mathrm{~m})$ & 29.7 & & \\
\hline $14^{\prime}$ & $1.32(\mathrm{~m})$ & 33.8 & & & $1.30-1.45(\mathrm{~m})$ & 29.5 & & \\
\hline $15^{\prime}$ & $1.50(\mathrm{~m})$ & 30.4 & & & $1.30-1.45(\mathrm{~m})$ & 29.3 & & \\
\hline $16^{\prime}$ & $0.94(t, 3.7)$ & 11.0 & & & $1.30-1.45(\mathrm{~m})$ & 29.5 & & \\
\hline $17^{\prime}$ & $0.99(\mathrm{~d}, 6.4)$ & 19.2 & & & $1.30-1.45(\mathrm{~m})$ & 29.6 & & \\
\hline $18^{\prime}$ & $0.90(\mathrm{~d}, 6.0)$ & 14.1 & & & $1.30-1.45(\mathrm{~m})$ & 29.4 & & \\
\hline $19^{\prime}$ & & & & & $1.30-1.45(\mathrm{~m})$ & 29.7 & & \\
\hline $20^{\prime}$ & & & & & $1.30-1.45(\mathrm{~m})$ & 29.7 & & \\
\hline $21^{\prime}$ & & & & & $1.30-1.45(\mathrm{~m})$ & 29.7 & & \\
\hline $22^{\prime}$ & & & & & $1.30-1.45(\mathrm{~m})$ & 29.7 & & \\
\hline $23^{\prime}$ & & & & & $1.27(\mathrm{~m})$ & 30.4 & & \\
\hline $24^{\prime}$ & & & & & $1.33(\mathrm{~m})$ & 23.0 & & \\
\hline $25^{\prime}$ & & & & & $0.91(t, 7.5)$ & 14.1 & & \\
\hline
\end{tabular}

respectively. Based on the above spectral data, the structure of compound 3 was defined as 29-benzoyl-3-octadecanoyl stigmasterol.
Compound 4 was isolated as a white powder. The ${ }^{1} \mathrm{H}$ NMR spectrum (Table 1) displayed three doublet of doublets peaks at $\delta_{\mathrm{H}} 5.35(1 \mathrm{H}, \mathrm{dd}, J=5.2,2.2 \mathrm{~Hz}), 5.15(1 \mathrm{H}, \mathrm{dd}, J=15.1$, 


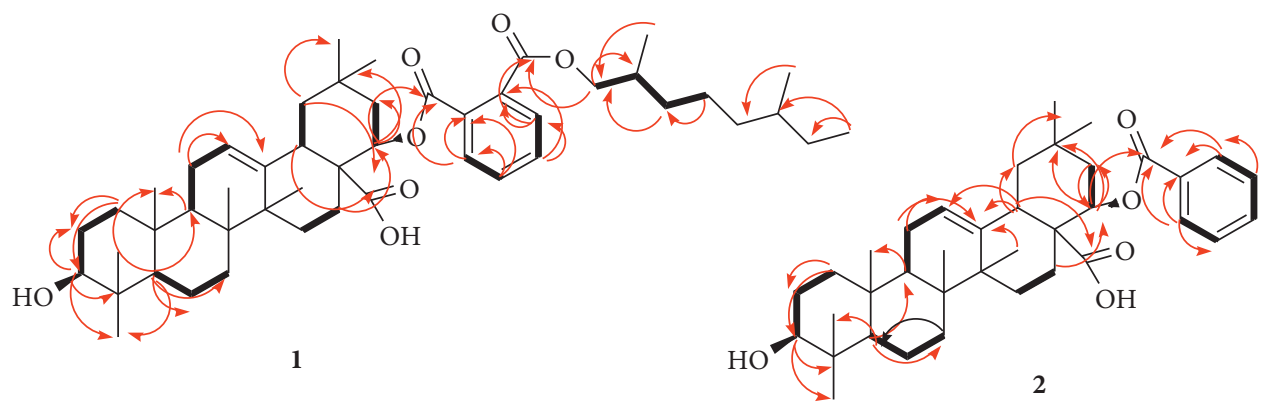

Figure 2: Key HMBC (curved arrow) and ${ }^{1} \mathrm{H}-{ }^{1} \mathrm{H}$ COSY (bold line) correlations of compounds 1 and 2.

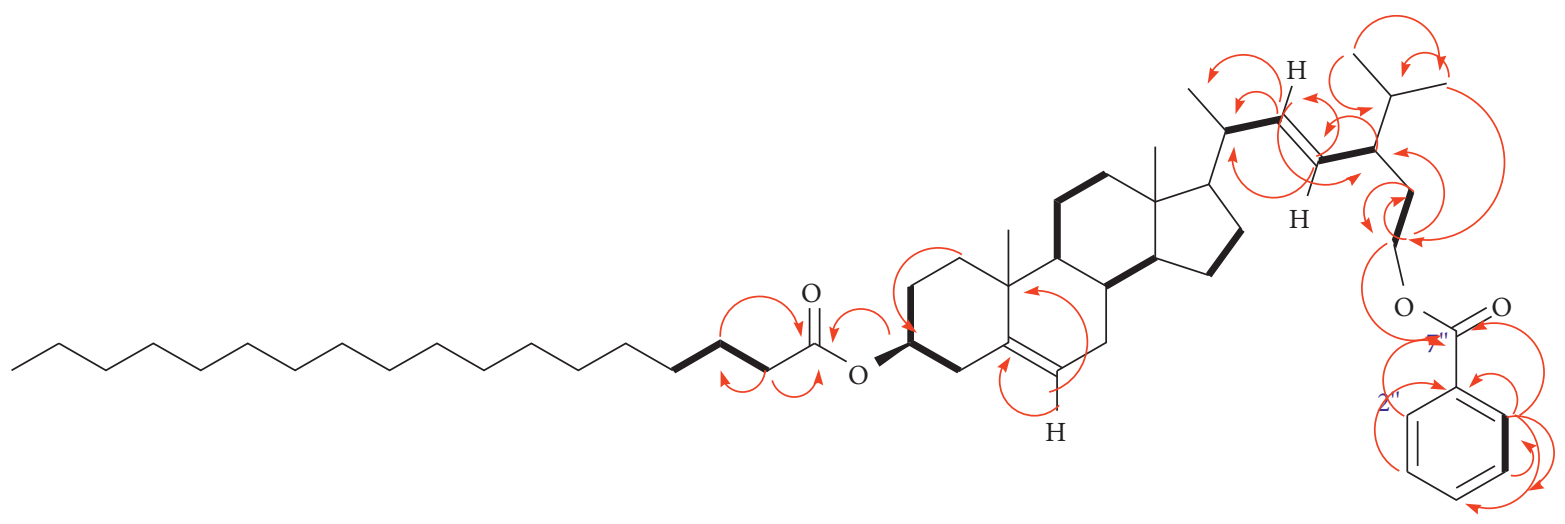

Figure 3: Key HMBC (curved arrow) and ${ }^{1} \mathrm{H}^{-1} \mathrm{H}$ COSY (bold line) correlations of compound 3.

TABLE 2: Bacterial growth inhibition zone in diameter $(\mathrm{mm})$ of crude extracts $(20 \mu \mathrm{g} / \mathrm{mL}$ each) and isolated compounds $(\mathbf{1}, \mathbf{2}$, and $\mathbf{4})(10 \mu \mathrm{g} /$ $\mathrm{mL}$ each).

\begin{tabular}{|c|c|c|c|c|c|}
\hline \multirow{2}{*}{ Compounds/extracts } & \multicolumn{5}{|c|}{ Tested micro-organism } \\
\hline & S. aureus & E. coli & P. aeruginosa & S. typhimurium & S. flexneri \\
\hline ME & 9 & 8 & 7 & 10 & 10 \\
\hline $\mathrm{PE}$ & 8 & 9 & 7 & 11 & 7 \\
\hline $\mathrm{CHE}$ & - & 7 & 11 & 7 & $14^{*}$ \\
\hline 1 & 7 & 7 & 7.2 & - & - \\
\hline 2 & - & 7.3 & 10 & 6.8 & 13 \\
\hline 4 & 7.4 & 7 & 7.3 & 13.2 & 6.9 \\
\hline Gentamycin & 16 & 21 & 14 & 20 & 24 \\
\hline
\end{tabular}

-, not active; ME, methanol extract; PE, petroleum ether extract; CHE, chloroform extract. All values are mean values \pm standard deviation of three replicates.

$8.7 \mathrm{~Hz})$, and $5.01(1 \mathrm{H}, \mathrm{dd}, J=15.2,8.7 \mathrm{~Hz})$, which are typical signals for olefinic proton $(\mathrm{H}-6)$ of the steroidal skeleton and olefinic protons ( $\mathrm{H}-22$ and $\mathrm{H}-23)$, respectively. The proton signal at $\delta_{\mathrm{H}} 3.52(1 \mathrm{H}, \mathrm{dd}, J=11.2,6.5,4.7 \mathrm{~Hz})$ integrating for $1 \mathrm{H}$ was indicative of hydroxymethine proton of $\mathrm{H}-3$. Two singlet peaks at $\delta_{\mathrm{H}} 0.86(3 \mathrm{H}, \mathrm{s})$ and $1.05(3 \mathrm{H}, \mathrm{s})$ were assigned to two tertiary methyl groups attached to $\mathrm{C}-13(\mathrm{H}-18)$ and $\mathrm{C}-10$ (H-19), respectively. The spectrum further revealed three doublet peaks at $\delta_{\mathrm{H}} 1.01(3 \mathrm{H}), 0.86(3 \mathrm{H})$, and $0.93(3 \mathrm{H})$ which are assigned to methyl groups at $\mathrm{C}-20(\mathrm{H}-21)$ and $\mathrm{C}-25$ (H-26 and $\mathrm{H}-27)$, respectively.

The ${ }^{13} \mathrm{C}$ NMR spectrum (Table 1) also showed the presence of 29 carbon atoms, of which the signal at $\delta_{\mathrm{C}} 71.8$ is assignable to C-3. The signals at $\delta_{\mathrm{C}} 140.8,121.7,138.3$, and 129.3 are corresponding to olefinic carbons at C-5, C-6,
C-22, and C-23, respectively. Based on these data and comparison to the reported literature [17-19], compound 4 was found to be stigmasterol. This is the first report of compound 4 from A. gummifera.

Compounds 1, 2, and 4 were evaluated for their antibacterial activities against five pathogenic bacteria strains: Staphylococcus aureus (ATCC25923), Escherichia coli (ATCC25922), Pseudomonas aeruginosa (ATCC27853), Salmonella typhimurium (ATCC13311), and Shigella flexneri (ATCC29903) (Table 2) using the disk diffusion method.

The crude extracts showed weak to moderate activity on both Gram-positive and Gram-negative bacterial strains with zone of inhibition ranging 7-14 $\mathrm{mm}$ with chloroform extract demonstrating the highest zone of growth inhibition $(14 \mathrm{~mm})(P<0.05)$ against $S$. flexneri. This is in agreement 
with the report that the hydroalcoholic extract of A. gummifera exhibited growth inhibition against bacterial pathogens $[6,20]$. The isolated compounds also showed moderate antibacterial activity against the test strains. These activities vary from strain to strain. Compound $\mathbf{4}$ showed significant inhibition $(13.2 \mathrm{~mm})$ against $S$. typhimurium (ATCC13311). Gram-negative bacteria showed greater susceptibility to $\mathbf{2}$ and $\mathbf{4}$ than Gram-positive. It might be due to the thickness of the peptidoglycan layer. It is worth to highlight that stigmasterol has been reported to inhibit several proinflammatory and matrix degradation mediators typically involved in human osteoarthritis- (OA-) induced cartilage degradation, at least in part through the inhibition of the NF- $\kappa$ B pathway [21]. It also showed good membrane stabilizing activity in HRBC with minimum stabilization $62.74 \%$ at $10 \mu \mathrm{g} / \mathrm{mL}$ and maximum stabilization $65.19 \%$ at $40 \mu \mathrm{g} / \mathrm{mL}[22]$.

The antibacterial activity results confirm the traditional value of the plant (A.gummifera), provided that these results further supported with in vivo and cytotoxicity tests.

\section{Conclusion}

Four triterpenoids 1, 2, 3, and 4 were isolated from stem bark of A. gummifera. This is the first report of compounds 1, 2, and 3 . The crude extract and isolated compounds showed moderate antibacterial activity with compound $\mathbf{4}$ exhibiting the highest. The observed antibacterial activities of the extracts and pure compounds could give insight about potential of the traditionally used medicinal plants for development of antibacterial drugs.

\section{Data Availability}

NMR data of compounds 1-4 are included in the Supplementary Materials.

\section{Conflicts of Interest}

The authors declare that they have no conflicts of interest.

\section{Acknowledgments}

Mr. Tamirat.T was thankful to Wollega University, Ethiopia, for financial support for his $\mathrm{PhD}$ study. This work was supported by the International Foundation for Sciences, Stockholm, Sweden, through a grant to Negera Abdissa (IFS, grant no.: $\mathrm{F} / 5778-2)$

\section{Supplementary Materials}

NMR data of compounds 1-4 are provided in the supplementary information. (Supplementary Materials)

\section{References}

[1] G. M. Rukunga and P. G. Waterman, "New macrocyclic spermine (budmunchiamine) alkaloids from Albizia gummifera: with some observations on the Structure-Activity relationships of the budmunchiamines," Journal of Natural Products, vol. 59, no. 9, pp. 850-853, 1996.
[2] M. Abdel-Kader, J. Hoch, J. M. Berger et al., "Two bioactive saponins from Albizia subdimidiata from the Suriname rainforest," Journal of Natural Products, vol. 64, no. 4, pp. 536-539, 2001.

[3] H. J. Beentje, Kenya Trees, Shrubs and Lianas, National Museums of Kenya, Nairobi, Kenya, 1994.

[4] K. Kokila, S. D. Priyadharshini, and V. Sujatha, "Phytopharmacological properties of Albizia species: a review," International Journal of Pharmacy and Pharmaceutical Sciences, vol. 5, no. 3, pp. 70-73, 2013.

[5] L. M. Simo, O. P. Noté, J. N. Mbing et al., "New cytotoxic triterpenoid saponins from the roots of Albizia gummifera C.A. Smith," Chemistry and Biodiversity, vol. 14, no. 10, pp. 01-22, 2017.

[6] Z. P. Mahlangu, F. S. Botha, E. Madoroba, K. Chokoe, and E. E. Elgorashi, "Antimicrobial activity of Albizia gummifera (J.F.Gmel.) C.A.Sm leaf extracts against four Salmonella serovars," South African Journal of Botany, vol. 108, pp. 132136, 2017.

[7] M. Tefera, A. Geyid, and A. Debella, "In vitro anti-Neisseria gonorrhoeae activity of Albiziagummifera and Croton macrostachyus," Pharmacology Oline, vol. 1, pp. 75-83, 2012.

[8] D. Nigussie, G. Tasew, E. Makonnen et al., "In-vitro investigation of fractionated extracts of Albizia gummifera seed against Leishmania donovani Amastigote Stage," Journal of J Clinical \& Cellular Immunology, vol. 6, no. 6, pp. 01-06, 2015.

[9] S. Cao, A. Norris, J. S. Miller et al., "Cytotoxic triterpenoid saponins of Albizia gummifera from the Madagascar rain Forest,1," Journal of Natural Products, vol. 70, no. 3, pp. 361-366, 2007.

[10] M. Meshesha, T. Deyou, A. Tedla, and N. Abdissa, "Chemical constituents of the roots of Kniphofia isoetifolia Hochst and evaluation for antibacterial activity," Journal of Pharmacy \& Pharmacognosy Research, vol. 5, no. 6, pp. 345-353, 2017.

[11] M. Kumara, R. Agarwala, K. Deyb, V. Raib, and B. Johnsonc, "Antimicrobial activity of aqueous extract of Terminalia chebula Retz. on gram positive and gram negative microorganisms," International Journal of Current Pharmaceutical Research, vol. 1, no. 1, pp. 56-60, 2009.

[12] H. Tedila and A. Assefa, "In vitro antibacterial activity of Rumexnervosusand Clematis simensisplants against some bacterial human pathogens," African Journal of Microbiology Research, vol. 13, no. 1, pp. 14-22, 2019.

[13] M.-Y. Baek, J. G. Cho, D. Y. Lee, E. M. Ahn, T. S. Jeong, and N. I. Baek, "Isolation of triterpenoids from the stem bark of Albizia julibrissin and their inhibition activity on ACAT-1 and ACAT-2," Journal of the Korean Society for Applied Biological Chemistry, vol. 53, no. 3, pp. 310-315, 2010.

[14] G. A. Meshram and S. S. Khamkar, "Effect of oleanolic acid isolated from garlic leaves on carbohydrate metabolizing enzymes, in Vitro," International Journal of Pharma Sciences and Research, vol. 5, pp. 988-991, 2014.

[15] M. Endo, K. Shigetomi, S. Mitsuhashi, M. Igarashi, and M. Ubukata, "Isolation, structure determination and structure-activity relationship of anti-toxoplasma triterpenoids from Quercus crispula Blume outer bark," Journal of Wood Science, vol. 65, no. 3, pp. 01-11, 2019.

[16] M. Zanger, "The determination of aromatic substitution patterns by nuclear magnetic resonance," Organic Magnetic Resonance, vol. 4, pp. 1-25, 1971.

[17] I. S. Okoro, T. A. Tor-Anyiin, J. O. Igoli, X. S. Noundou, and R. W. M. Krause, "Isolation and characterisation of stigmasterol and $\beta$-sitosterol from Anthocleista djalonensis 
A. Chev," Asian Journal of Chemical Sciences, vol. 3, no. 4, pp. 1-5, 2017.

[18] K. M. Kumari, "Isolation and characterization of bio active triterpenes and phytosterols from Alysicarpus monilifer L," International Journal of Current Microbiology and Applied Sciences, vol. 5, pp. 60-66, 2017.

[19] M. Haque, N. Sultana, S. Abedin, and S. Kabir, "Stigmasterol, rengyolone, 2 -phenylethyl $\beta$-D-glucopyranoside and $n$-tetradecyl- $\beta$-D-glucopyranoside from the flowers of Nyctanthes arbor-tristis Linn," Bangladesh Journal of Scientific \& Industrial Research, vol. 54, no. 3, pp. 275-282, 2019.

[20] G. Tesfamaryam, B. Tsegaye, T. Eguale, and A. Wubete, "In vitro screening of antibacterial activities of selected Ethiopian medicinal plants," International Journal of Microbiological Research, vol. 6, no. 1, pp. 27-33, 2015.

[21] O. Gabay, C. Sanchez, C. Salvat et al., "Stigmasterol: a phytosterol with potential anti-osteoarthritic properties," Osteoarthritis and Cartilage, vol. 18, no. 1, pp. 106-116, 2010.

[22] M. Aurang, S. U. Khan, T. U. Rahman, M. Sajid, and S. Seloni, "Isolation and biological activity of $\beta$-sitosterol and stigmasterol from the roots of Indigofera heterantha," Pharmacy \& Pharmacology International Journal, vol. 5, no. 5, pp. 204-207, 2017. 